\title{
PERSONALIZM TOMISTYCZNY WOBEC NOWOCZESNEJ I PONOWOCZESNEJ ANTROPOLOGII
}

Profesor Mieczysław Gogacz uważa, że od czasów antycznych do dziś platonizm i arystotelizm to dwie drogi do metafizyki ${ }^{1}$. Metafizyka zaś w sensie klasycznym to zespół podstawowych pytań i odpowiedzi - np. czy coś jest i czym to jest - które znajdują się w zapleczu każdej dziedziny wiedzy bez względu na to jak metodologicznie jest to w niej usytuowane. Co więcej pytania te - pytania par excellence filozoficzne - dotyczą każdego człowieka, który wcześniej czy później musi postawić kwestię przyczyny swego pojawiania się na ziemi, celu i sensu własnego istnienia, charakteru swoich relacji z innych ludźmi, dlatego Jan Paweł II napisał, że „,człowiek zaś jest z natury filozofem"2. Podstawowa zaś różnica między platonizmem i arystotelizmem - najpierw teoriopoznawcza - jest taka, że w platonizmie wiedzy o świecie szukamy w sobie, w arystotelizmie natomiast - na zewnątrz. Przekłada się to bezpośrednio na rozumienie samej rzeczywistości, którą w platonizmie są przedmioty pojęć, idee, znajdujące się na pewno w naszym umyśle, ale ich byt - najbardziej rzeczywisty jak to możliwe według zapewnień Platona - jest naszemu

Zob. M. G o g a c z, Platonizm i arystotelizm (dwie drogi do metafizyki), Warszawa 1996.

2 J a n P a w e 1 I I, Encyklika Fides et Ratio, 64, w: Encykliki Ojca Świętego Jana Pawła II, Kraków 2007, s. 1152. 
bezpośredniemu poznaniu całkowicie niedostępny, a wyłącznie ich zapamiętany ślad znajduje się w naszym umyśle. Dlatego poznanie w platonizmie to myślenie - poszukiwanie w swojej świadomości wiedzy, która tam od zawsze się znajduje. W arystotelizmie odwrotnie: ujmujemy poznawczo wyłącznie otaczające nas przedmioty zawierające w swej strukturze materię i w mozolnym trudzie analizy danych poznawczych, polegającej na pytaniu o przyczyny obserwowanych skutków, staramy się zbudować maksymalnie adekwatną odpowiedź na pytanie, czym jest oddziałujący na mnie przedmiot. Rzeczywistość więc dla Arystotelesa to świat jednostkowych bytów, powiązanych różnorodnymi relacjami, które ludzki intelekt stara się ująć, zrozumieć, jakoś sklasyfikować i wyjaśnić.

Tak bardzo różne rozumienie rzeczywistości i sposobu jej poznawania przekłada się w bezpośredni sposób na rozumienie samego podmiotu poznającego - człowieka. Dla Platona i tradycji przez niego wyznaczonej człowiek to dusza pozostająca tymczasowo w niejasnym, niezrozumiałym i nieakceptowalnym związku z materialnym ciałem. Ten pogląd musiał ulec pewnej modyfikacji w chrześcijaństwie z powodu wcielenia Chrystusa i zapowiedzi zmartwychwstania ciał, ale jej zasadniczy rys pozostaje niezmienny: człowiek to połączenie dwóch bardzo różnych i słabo przystających do siebie elementów. Człowiek więc zasadniczo nie jest tym, kim nam się jawi w bezpośrednim poznaniu. Jest kimś innym, kimś, kim stanie się dopiero w przyszłości. Ludzie na ziemi to dopiero „,zadatek na człowieka", prawdziwe człowieczeństwo musimy dopiero uzyskać. Dla Arystotelesa i (przynajmniej dla części) tradycji, która się na niego powoływała, człowiek jest duchowo-cielesną jednością. Jego struktura jest stała i wykończona: forma stanowi duszę człowieka zaś ciało jego materię, połączenie duszy z ciałem jest więc połączeniem formy i materii jako aktu i możności. Jest to połącznie stałe, wyznaczające naturę człowieka, która zatem w tych podstawowych elementach jest zawsze taka sama. Ewentualne przekształcenia dokonują się w obrębie możności w zakresie określonym przez akt. W duszy znajduje się intelekt, który za pośrednictwem cielesnych zmysłów poznaje 
otaczającą człowieka rzeczywistość bytów jednostkowych, starając

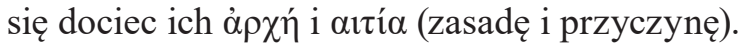

Obydwie te wizje człowieka przejęło chrześcijaństwo i w jego łonie przez setki lat te wykluczające się ujęcia wiodły ze sobą spór ${ }^{3}$. Przy czym otwarcie trzeba przyznać, że wizja platońska była powszechniejsza, dawała większe pole dla twórczości, bardziej poddawała się metaforze i poezji, była ulubioną formą literacką teologów i mistyków. Uległo jej wielu Ojców Kościoła z Augustynem na czele i wielu mistyków na czele z Bernardem z Clairvaux. Ujęcie arystotelesowskie odpowiadało nielicznym teologom, zainteresowanym przede wszystkim ukazaniem teologii dogmatycznej w maksymalnie jednoznaczny sposób, unikający metafor i poetyckich analogii. Koniecznie trzeba też dodać, że nieliczne antropologiczne interwencje Magisterium Kościoła stawały jeśli nawet nie dość jednoznacznie po stronie arystotelesowskiej wizji człowieka, to przynajmniej zdecydowanie przeciwko jej platońskim skrajnościom ${ }^{4}$. Nasza zsekularyzowana epoka dziedziczy obydwie opisane wizje człowieka i co ciekawe najbardziej nawet szokujące ujęcia bytu ludzkiego mają swe pierwotne źródło w platonizmie przekazanym nam przez pisarzy chrześcijańskich ${ }^{5}$.

Tytułowy personalizm tomistyczny w artykule rozumiany jest bardzo szeroko: jest to tomistyczna teoria człowieka jako osoby wraz ze wszystkim konsekwencjami tego ujęcia, w Polsce reprezentowana przez takich autorów jak Karol Wojtyła, Mieczysław Krąpiec,

3 Najostrzej zarysował się on w XIII wieku na Uniwersytecie Paryskim angażując największe umysły epoki: Alberta Wielkiego, Tomasza z Akwinu, Bonawenturę, Jana Peckhama, Sigera z Brabancji i innych.

4 Sobór Konstantynopolitański IV (VIII Sobór Powszechny, 869-870), Sobór w Vienne (XV Sobór Powszechny, 1311-1312), Sobór Laterański V (XVIII Sobór Powszechny, 1513).

5 Ciekawie ukazuje to Rafał Tichy na przykładzie transhumanizmu, zob. R. T i chy, Gwiazdy naszym przeznaczeniem. Chrześcijańskie korzenie transhumanizmu, „Czterdzieści i cztery. Magazyn Apokaliptyczny”, 8 (2016), s. 4-43 oraz Tenże, Mesjańskie oblicze transhumanizmu, „Czterdzieści i cztery. Magazyn Apokaliptyczny", 8 (2016), s. 164-183 (szcz. 180-182). 
Mieczysław Gogacz, Czesław Bartnik i wielu innych ${ }^{6}$. Nowoczesność (modernizm) w teorii człowieka dla potrzeb tego artykułu datujemy od ogłoszenia przez Karola Darwina pracy On the Origin of Species (O powstawaniu gatunków) w $1859^{7}$. Za początek ponowoczesności (postmodernizmu) przyjmuje się publikację w 1979 książki ,papieża postmodernizmu" Jean-François Lyotarda (1924-1998) pt. La Condition postmoderne. Rapport sur le savoir (Kondycja ponowoczesna. Raport o stanie wiedzy) ${ }^{8}$.

\section{ANTROPOLOGIA MODERNIST YCZNA: CZLOWIEK JAKO PRODUKT EWOLUCJI}

Raz po raz pojawiały się koncepcje człowieka, które trudniej było wbudować w chrześcijańską wizję Boga i świata, ale teorią, która w sposób zasadniczy i radykalny podważyła nie tylko akt stwórczy Boga, alei istnienie Jego samego, był ewolucjonizm. Na fali burzliwego rozwoju nauk przyrodniczych i fascynacji nimi filozofów przeniesiono bardzo szybko idee sformułowane w biologii do innych dziedzin wiedzy, uznając ewolucjonizm za najlepsze narzędzie wyjaśniania zjawisk w wielu naukach i dziedzinach życia (antropologia, kulturoznawstwo, socjologia, ekonomia, językoznawstwo $\mathrm{i}$ inne). Oczywiście, niemal od powstania ewolucjonizmu, myśliciele chrześcijańscy upominali się o uwzględnienie w nim stwórczego aktu Boga, ale ich głos nie został jakoś szerzej uwzględniony i do dziś ewolucjonizm jest traktowany jako argument ateistyczny. A sam

6 Zob. A. A ndrzeju k, Jaki personalizm? Szerokie $i$ waskie rozumienie personalizmu, w: P. D a n cá k i inni (red.), Personalizmus a súčasnost'. Zborník príspevkov z medzinárodnej vedeckiej konferencie, Prešov 2010, s. 19-25.

7 Chociaż właściwym twórcą ewolucjonizmu jako teorii wyjaśniającej wielość zjawisk w wielu dziedzinach jest Herbert Spencer, który ogłosił ją w książce Social Statics (Statyka społeczna) z 1851 r. jednak dopiero po publikacji Darwina filozoficzny ewolucjonizm Spencera nabrał „naukowego” uprawomocnienia i stał się wspomnianą w artykule ,superteorią".

8 Wydanie polskie: Kondycja ponowoczesna. Raport o stanie wiedzy, (tłum.) M. Kowalska, J. Migasiński, Warszawa 1997. 
ewolucjonizm stał się w nauce paradygmatem niepodważalnym (superteorią) i każdy, kto zgłaszałby wobec niego jakieś wątpliwości, uznany zostałby w najlepszym wypadku za ignoranta.

W odniesieniu do teorii człowieka modyfikacje, które wprowadził ewolucjonizm, były znaczne i wielopłaszczyznowe. Przede wszystkim człowieka ogłoszono potomkiem małp człekokształtnych i że jak one jest człowiek ssakiem łożyskowym z tym, że ma wśród wszystkich zwierząt mózg najlepiej dostosowany do myślenia abstrakcyjnego. W systematyce biologicznej Homo sapiens został przedstawicielem ssaków naczelnych (Primates), i ściślej - małp wąskonosych ( $\mathrm{Ca}$ tarrhini). Człekokształtne naczelne wyróżnia brak ogona, większe rozmiary ciała i powiększony w stosunku do masy ciała mózg. Do człowiekowatych (Hominidae) zalicza się obecnie obok człowieka jego wymarłych poprzedników oraz orangutany, goryle i szympansy. Ewolucjonizm wykorzystano w medycynie (budowa mózgu, w której wyróżniono warstwy „starsze” i „młodsze”), a przede wszystkim w psychologii, która radykalnie odrzuciła swą racjonalną (filozoficzną) wersję na korzyść biologicznej, w której psychika jest tylko funkcją ciała i właściwie psychologia człowieka jest przedłużeniem zoopsychologii. Pewnego znaczenia nabrała ta psychologia we współczesnej epistemologii genetycznej (Jean Piaget), a zwłaszcza modnej dziś kognitywistce.

Niejako odpowiedzią na ten zdecydowany redukcjonizm w odniesieniu do człowieka, filozofowie tomistyczni rozwinęli teorię osoby, a przede wszystkim jej aplikację do bytu ludzkiego. To, że człowiek jest osobą, wiedziano już od czasów Boecjusza (480-525), który definicję osoby sformułował, ale zarówno on sam, jak i liczni zwolennicy jego definicji, z Tomaszem z Akwinu na czele, wykorzystywali ją w opisie osób Trójcy Świętej, jakby mimochodem wspominając, że oczywiście człowiek jest też osobą i to zresztą stanowi o jego podobieństwie do Boga. Szersze wykorzystanie pojęcia osoby $\mathrm{w}$ antropologii dokonało się dopiero w czasach nowożytnych i nie jest zresztą dziełem wyłącznie tomistów; korzystali z niego John Locke (1632-1704), Immanuel Kant (1724-1804), Max Scheler (1874-1928), Roman Ingarden (1893-1970) i inni. Jednakże to tomiści uczynili z niej 
naczelne pojęcie antropologiczne. Wiąże się to z nazwiskami następujących filozofów: Emanuel Mounier (1905-1950), Jacques Maritain (1882-1973), Karol Wojtyła - Jan Paweł II (1920-2005), Mieczysław Krąpiec (1921-2008), Mieczysław Gogacz (ur. 1926), Czesław Bartnik (ur. 1929) i inni. Mimo różnic w ujęciach szczegółowych problemów, pewien fundament tego, czym jest osoba, jest wspólnym dziedzictwem różnych nurtów tomizmu. Ten fundament sprowadza się do klasyfikacji charakterystycznych cech osoby ludzkiej (constitutiva personae). Są nimi (w ujęciu M. A. Krąpca):

„Intelektualne poznanie, miłość, wolność; są to cechy, które ujawniają transcendencję i godność człowieka w stosunku do natury. Akty poznania, miłości i wolności wzajemnie na siebie oddziałują, w wyniku czego poznanie jest wolne, selektywne, wyłonione pod wpływem miłości. Osobowa miłość jest miłością ducha - trwałego chcenia, wolna. Wolność jest rozumna, kierująca się racjonalnym chceniem, czyli miłością odpowiedzialną. Takie zespolenie intelektualnego poznania, rozumnego chcenia-miłości i wolności działania zasadniczo różni człowieka jako osobę od innych bytów. Jawiąca się w osobowym działaniu synteza intelektualnego poznania, duchowej miłości i racjonalnej, odpowiedzialnej wolności stanowi podstawę, dla której o sobie mówimy «ja», doświadczając siebie jako istniejącego realnie podmiotu. Istnieją trzy inne cechy bytu osobowego związane z życiem społecznym człowieka: podmiotowość prawa, zupełność bytowa oraz godność, które wzajemnie się warunkują, suponując intelektualne poznanie, duchową miłość oraz odpowiedzialną wolność"9.

9 M. K r ą p i e c, Osoba, w: A. M a r y n i a r c z y k (red.), Powszechna Encyklopedia Filozofii, t. 7, Lublin 2006, s. 881. 
Tak - maksymalistycznie - pojęty byt ludzki stawał w opozycji wobec każdego redukcjonizmu: biologicznego, socjologicznego, kulturowego, ekonomicznego, prawniczego. Człowiek jako osoba wyrastał ponad to, co fizyczne, także ponad swoje ciało, które stanowiąc integralną część bytu ludzkiego nie wchodziło do definicji osoby. Można nawet powiedzieć, że w tomizmie to osoba ludzka przyjmuje ciało. Takie ujęcie człowieka powoduje, że nie można go zredukować do jego ciała, co jest oczywiste, ale także, że cielesność człowieka nie stanowi centralnego tematu antropologii, gdyż jest nim osoba. Powoduje to w konsekwencji odsunięcie na dalszy plan problemu pochodzenia ciała i z tej perspektywy nawet przyjęcie ewolucyjnej genezy organów cielesnych nie stanowi podstawy do negowania stwórczej roli Boga w powstawaniu człowieka. W tomizmie egzystencjalnym to dzieło Boga polega na stworzeniu aktu istnienia, zapoczątkowującym człowieka i zresztą każdy inny byt. W tym działaniu nikt Boga zastąpić nie może, gdyż tylko On ma strukturę ontyczną umożliwiającą Mu stwarzanie istnień.

\section{ANTROPOLOGIA POSTMODERNIZMU: CZLOWIEK O „PLYNNEJ TOŻSAMOŚCI”}

$\mathrm{Na}$ antypodach modernistycznego redukcjonizmu stoi jego negacja w postaci postmodernizmu (ponowoczesności). Wprawdzie sam termin oznacza sprzeciw wobec modernizmu (,,krach projektu modernistycznego"), który postmoderniści datują od okresu oświecenia, to jednak postmodernizm stanowi radykalne zanegowanie całej tradycyjnej filozofii greckiej, przynajmniej od czasów Sokratesa, poprzez wszystkie jej średniowieczne i nowożytne przekształcenia z racjonalizmem, scjentyzmem i utopizmem na czele. Wszystko to bowiem według postmodernistów stanowi przejaw „totalitarnej mentalności ateńskiej”, której najbardziej charakterystyczną cecha jest ,logocentryzm”, czyli przekonanie o istnieniu prawdy obiektywnej. Powoduje to powstanie - ,wielkich narracji metafizycznych" oraz „filozofii wyrokujących”, skutkujących tworzeniem „opresywnych” teorii społecznych. W filozofii greckiej dominuje „myśl mocna”: 
aksjomaty, tezy, twierdzenia, dowody, którym zawsze sprzeciwiają się inne aksjomaty, inne tezy, inne twierdzenia i inne dowody, a które w imię ,prawdy" swoich własnych tez trzeba konsekwentnie odrzucać. Uwolnienie od tego może się dokonać wyłącznie poprzez „odrzucenie hipoteki metafizycznej” i uwolnienie dyskursu od „filozofii pierwszych zasad”. „Myśl mocną” powinna zastąpić „myśl słaba": przypuszczenia, prawdopodobieństwo, wątpliwości, poglądy uznające alternatywę ${ }^{10}$. Richard Rorty (1931-2007) w tym kontekście przypomina pojęcie „przygodności”, które ma wskazywać na indywidualność, różnorodność, brak możliwości jednej metafizyki, która mogłaby obejmować wszystkie przedmioty. Na bazie tego terminu Rorty proponuje wizję „liberalnej ironistki”, czyli kogoś, kto dystansuje ,przygodność" - nawet też tę, która jest zawarta w jej własnych przekonaniach. „Liberalna ironistka” wyznaje historycyzm (ujmowanie zjawisk z punktu widzenia ich historycznej ewolucji) i nominalizm (istnieją tylko jednostki i ich konwencjonalne nazwy), dzięki czemu może porzucić wszelkie metanarracyjne próby opisu istoty rzeczy. Tworzy za to własny język metafor, którego może używać w sposób całkowicie swobodny i dowolny. Podobnie inni ludzie. Rorty podkreśla jednak, że „liberalna ironistka” ma dystans do swej wizji świata, która jest tylko jedną z wielu możliwych. Posiada świadomość, że niekoniecznie jest bliżej rzeczywistości niż inni ${ }^{11}$. To ostatnie przeświadczenie niekoniecznie jest podzielane przez lewicowe i ekologiczne ruchy społeczne, których ideologami są filozofowie postmodernistyczni. Zwalczając różne „esencjalizmy” lub ,centryzmy” (,logocentryzm”, „ontocentryzm”, „theocentryzm”, „phallocentryzm”, a także rasizm i homofobia) tworzą nowe (,ekocentryzm”). Mieści się to jednak w wizji ponowoczesności, gdyż według jej teoretyków człowiek ma wbudowany „mechanizm totalizacji”

10 Zob. M. S u r m a - G a w ł o w s k a, A. Z a w a d z k i (wybór, przekład i opracowanie), Myśl mocna, myśl słaba. Hermeneutyka włoska od połowy XX wieku. Antologia tekstów, Kraków 2015.

11 R. R o r t y, Przygodność, ironia i solidarność, (tłum.) J. W. Popowski, Warszawa 2008. 
(„pęd do uogólniania”, „pokusa metafizyki”), czyli skłonność do przedkładania założeń nad fakty i ogółu nad jednostki, co pociąga za sobą przemoc społeczną i unifikację kulturową. Oczywiście celem postmodernizmu jest „decentryzm” (,antyesencjalizm”) wszelkich „centryzmów”, do którego drogą są asystemowość i pararacjonalność („kazirodcze rozplenienie sensów”, „dialektyczne” potraktowanie różnic i podobieństw, „pluralizacja dyskursu”, „przeniesienie sensu na margines" i na ,to, co poza nawiasem”). Celem ostatecznym jest zastąpienie modernistycznych ,metanarracji” ponowoczesnymi „mikronarracjami” (,mikrologiami”, ,grami kulturowymi”, ,pastiszami”, „kolażami”).

Z punktu widzenia teorii człowieka jako osoby postmodernizm jawi się dość interesująco. Jest bowiem reakcją na ten sam redukcjonizm biologiczno-społeczno-kulturowy, jaki zafundowała człowiekowi nauka XIX i XX wieku z jej scjentyzmem i technokracją. Wydaje się, że w tym kontekście można zwrócić uwagę na klasyczne cechy osoby (constitutiva personae), takie jak jednostkowość, intelektualny charakter i wolność osoby ludzkiej, które w sumie powodują jej podmiotowość i daleko idącą autonomię.

Jednostkowość oznacza z jednej strony, że osobą może być tylko istota jednostkowa, nie zaś instytucje i jakiekolwiek ,bytowania kolektywne”. Tzw. więc „osobowość prawna”, czyli stanowienie „osoby prawnej” nie ma nic wspólnego z filozoficznie pojętą osobą jako rationalis naturae individua substantia. Jednostkowość w sensie bytowym oznacza indywidualny charakter każdej osoby, jej niepowtarzalność, nieredukowalność do czegokolwiek innego, skupienie w sobie wszystkich właściwych osobie cech i własności. Ten wybitnie indywidualny charakter każdej osoby ludzkiej w dobitny sposób przeciwstawia się wszelkim jej kolektywnym ujęciom i takiemuż traktowaniu. Bycie człowiekiem nie polega w swej istocie na stanowieniu elementu społeczeństwa, państwa, świata przyrody, kosmosu, mimo że człowiek buduje różne społeczności, uczestniczy w różnych instytucjach, żyje w otoczeniu przyrodniczym, z którego korzysta i z którym jest związany całym systemem powiązań (nie tylko biologicznych, lecz także np. estetycznych). Akcent na jednostkowości, 
autonomii i niepowtarzalności człowieka jako osoby odpowiada na pewną cześć postulatów postmoderny, szczególnie „decentryzmu” różnych redukcjonistycznych ,centryzmów”, które prowadzą człowieka do „świata koszarowego”.

Intelektualność człowieka oznacza przede wszystkim możliwość zasadniczo niczym nie zdeterminowanego poznawczego ujmowania i rozumienia świata otaczających go bytów. Intelektualność przekracza zmysłowe poznanie empiryczne, nie jest też redukowalne do uczuć, emocji, „inteligencji emocjonalnej”, przeczuć, intuicji, zjawisk parapsychicznych. Stanowi normalne ludzkie poznanie, będące wysiłkiem maksymalnie adekwatnego ujęcia przedmiotu. To ujęcie nie jest proste, wymaga pewnej dozy wysiłku, odróżnienia treści zmysłowych od treści intelektualnych, pamiętania o aspektowości ludzkiego poznania, rozumowania, które jest rodzajem dyskursu między poznawanym przedmiotem i poznającym intelektem oraz pomiędzy już ujętymi treściami. Celem poznania jest oczywiście ujęcie prawdy, która jednak nie jest, jak piszą postmoderniści, „wyrokiem”, podstawą „opresji” społecznych, zamknięciem w „koszarach”, lecz jako adequatio rei et intellectus stanowi wysiłek ludzkiego intelektu coraz bardziej wszechstronnego, precyzyjniejszego, pełniejszego ujęcia poznawanej rzeczy. W tym wysiłku dokonuje się właśnie wspomniana ,adekwacja”. Losem zatem ludzkiego poznania jest prawdziwość. Ta zaś zawsze może być poprawiona, doprecyzowana, uzupełniona. Nie znaczy to więc, że tomizm głosi naiwny przesąd, że prawda da się jednoznacznie ująć i wyrazić w ustalonej raz na zawsze definicji. Żyjący w XIV wieku Gilbert z Tournai pisał wprost, że ,nigdy nie odnajdziemy prawdy, o ile zadomowiliśmy się w tym, co już zostało odkryte. Ci, którzy pisali przed nami, nie są naszymi władcami, tylko przewodnikami. Prawda stoi otworem dla wszystkich, jej miejsce przez nikogo nie zostało jeszcze zajęte"'12. Wydaje się więc, że w krytyce postmoderny prawdę myli się z pewnością. Tymczasem pewność jest aktem decyzyjnym, a nie poznawczym.

12 M. D. C h e nu, Wstęp do filozofii św. Tomasza z Akwinu, (tłum.) H. Rosnerowa, Warszawa 1974, s. 78. 
Nabycie pewności kończy proces dowiadywania się, kończy więc poznanie. Faktem jest, że człowiek pragnie pewności, pozwala mu ona spokojnie podejmować decyzje. Faktem jest także, iż wielokrotnie w dziejach prawdę zastępowano pewnością i w jej imię prześladowano myślących inaczej. Faktem jednak jest także, że ludzkie poznanie bardzo rzadko daje podstawy do nabywania pewności, jest raczej skazane na prawdziwość (właśnie ową ,adekwację") i ciągły o nią niepokój, że można ją ująć precyzyjniej, szerzej, pełniej. Można więc powiedzieć, że to pewność jest „myślą mocną”, prawdziwość jest zawsze „słaba”, zawsze bowiem otwarta na krytykę, poprawianie, doprecyzowania. Krytykując zatem „myśl mocną” postmoderniści krytykują raczej ideologizację nauki, wykorzystywanie jej jako narzędzia władzy, zniewolenia, opresji. Filozofię klasyczną, a w niej nawet metafizykę, jak pisał Mieczysław Gogacz, „należy precyzować, poprawiać, uzupełniać, przeformułowywać, gdyż interesuje nas i jest dla nas ważna prawda o bycie, a nie stanowiący metafizykę układ zdań. Metafizyk nie broni metafizyki, broni zawsze rzeczywistości, a tym samym prawdy o bytach. Jest wierny istnieniu i istocie bytu, a nie ujęciom i wiedzy"13.

\section{ANTROPOLOGIA TRANSHUMANIZMU: OD TRANSCZLOWIEKA DO POSTCZLOWIEKA}

Najmłodszymi, jak się wydaje, „dziećmi” ponowoczesności są transhumanizm i posthumanizm ${ }^{14}$. Początkowo, w wersji biologa Juliana Huxleya (1887-1975), transhumanizm oznaczał przyspieszenie i takie ukierunkowanie ewolucji, aby „,człowiek pozostający człowie-

\footnotetext{
13 M. G o g a c z, Elementarz metafizyki, Warszawa 2008, s. 12.

14 Dodać może należy, że nazw ,transczłowiek” i ,postczłowiek” używa się w odniesieniu do ,skutków” przemiany człowieka. Terminologia ta jest wspólna dla ideologii i ruchu, który nazywa się „transhumanizmem”, epokę zaś dziejów, która nastąpi, gdy pojawi się ,postczłowiek”, nazwano ,posthumanizmem”. Nie ma zatem analogii pomiędzy parami określeń: „transczłowiek” - „transhumanizm” oraz ,postczłowiek” - ,posthumanizm”, gdyż transhumanizm oznacza ideę, a posthumanizm - przyszłą epokę.
} 
kiem, ale wykraczającym poza siebie przez zrealizowanie nowych możliwości odnoszących się do jego natury"15. Jednak bardzo szybko określenie to okazało się ,przestarzałe” i Max More zaproponował zastąpić je następującą definicją:

„Transhumanizm jest kategorią filozoficzną, która chce nas prowadzić ku kondycji postludzkiej. Transhumanizm podziela wiele elementów humanizmu, przede wszystkim szacunek dla rozumu i nauki, nacisk na postęp i akcentowanie roli człowieczeństwa (czy transczłowieczeństwa) w tym życiu, a nie w jakimś nadprzyrodzonym «życiu pozagrobowym». Transhumanizm różni się od humanizmu w rozpoznawaniu i przewidywaniu radykalnych zmian natury i możliwości naszego życia wynikających z rozwoju różnych nauk i technologii, takich jak neurologia i neurofarmakologia, wydłużanie życia, nanotechnologia, sztuczna ultrainteligencja i zamieszkiwanie przestrzeni kosmicznej, co łączy z racjonalną filozofią i systemem wartości"'16.

Transhumanizm zatem postuluje szerokie wykorzystanie nauk medycznych (łącznie z manipulacjami kodem DNA) i zaawansowanej technologii w rozwój człowieka, doprowadzających do jego

15 J. H u x le y, In New Bottles for New Wine, London 1957, s. 17: “man remaing man, but transcending himself, by realizing new possibilities of and for human nature".

16 M. M o r e, Transhumanism: Towards a Futurist Philosophy, „Extropy \#6”, 1990, s. 6-12: „Transhumanism is a class of philosophies that seek to guide us towards a posthuman condition. Transhumanism shares many elements of humanism, including a respect for reason and science, a commitment to progress, and a valuing of human (or transhuman) existence in this life rather than in some supernatural »afterlife«. Transhumanism differs from humanism in recognizing and anticipating the radical alterations in the nature and possibilities of our lives resulting from various sciences and technologies such as neuroscience and neuropharmacology, life extension, nanotechnology, artificial ultraintelligence, and space habitation, combined with a rational philosophy and value system". 
gatunkowej przemiany w postczłowieka i rozpoczynających nową epokę dziejów, zwaną posthumanizmem. „Transhumaniści mają nadzieję - pisał Nick Bostrom (ur. 1973), jeden z głównych dziś ideologów transhumanizmu - że poprzez odpowiedzialne wykorzystanie nauki, techniki i innych racjonalnych środków uda nam się ostatecznie stać się postludźmi, czyli istotami o znacznie większych możliwościach niż obecne istoty ludzkie"17.

Podstawową nauką transhumanizmu jest nanotechnologia, w której głosi się możliwość zbudowania każdej możliwej do określenia struktury fizyko-chemicznej. Nanotechnologia ma dać postczłowiekowi dokładną i tanią kontrolę nad strukturą materii, pozwoli na konstrukcję superszybkich komputerów, maszyn naprawiających komórki, osobistych urządzeń produkcyjnych, taniego sprzętu do zasiedlenia kosmosu, i wielu innych rzeczy. Kolejnym postulatem posthumanizmu jest superinteligencja, przez którą rozumie się intelekt znacznie przewyższający najlepsze mózgi ludzkie we wszystkich dziedzinach, włączając w to twórczość naukową (także problematykę filozoficzną), ogólną mądrość, czy też umiejętności towarzyskie. Ma się to stać przez ,przelanie” lub „skopiowanie” ludzkiej świadomości do komputera. Powstanie superinteligencji będzie oznaczało kres człowieka, gdyż wtedy to ona przejmie badania i rozwój naukowy - ludzie przestaną być do tego potrzebni. Radykalnie zwiększona moc obliczeniowa komputerów oraz udoskonalenie czujników i ekranów ma spowodować, że wirtualna rzeczywistość otworzy możliwość nieograniczonej twórczości i pomysłowości. Ludzie stworzą sztuczne, eksperymentalne światy, w których prawa fizyki nie muszą obowiązywać. Będzie można odwiedzać te światy dla rozrywki, pracy lub w celach towarzyskich, spotykając się z innymi, którzy fizycznie mogą znajdować się na innych kontynentach. Dla

17 N. B o s t r o m, Transhumanist Values, w: F. A d a m s (red.), Ethical Issues for the 21st Century, Philosophical Documentation Center Press, Charlottesville 2003, s. 3-14: „Transhumanists hope that by responsible use of science, technology, and other rational means we shall eventually manage to become posthuman, beings with vastly greater capacities than present human beings have". 
tych „nauk przyszłości” stosuje się wspólną nazwę GRIN jako współdziałanie czterech głównych technologii: genetyka $(\mathrm{G})$, robotyka $(\mathrm{R})$, informatyka (I) i nanotechnologia (N). Hipotetycznym punktem zwrotnym ma być „technologiczna osobliwość”, kiedy to krzywa postępu technologicznego zbliży się do pionu (w funkcji czasu), co będzie oznaczało niewyobrażalnie szybki rozwój. Można powiedzieć, że będzie to „koniec człowieka”"18 i początek postczłowieka.

Postczłowieka mają charakteryzować przede wszystkim nadzwyczajne zdolności umysłowe i szybkość myślenia, połączone z absolutną pamięcią i zdolnością do błyskawicznego przyswajania informacji. Także struktura fizyczna ma ulec tak radykalnemu przekształceniu, że zniknie konieczność dbania o ciało oraz ograniczenia wynikające z cielesności (np. komunikacyjne). Człowiek nie będzie chorować, ani starzeć się. Przypadkowe zranienia będą „naprawiane” samoistnie. Człowiek wyzbędzie się także swoich największych wad: nadpobudliwości, chciwości, żądzy władzy, gdyż będzie całkowicie panował nad swoimi emocjami. Co więcej, panowanie to sprawi, że życie będzie nieustanną przyjemnością. Planuje się, że w przyszłości postludzie otrzymają dodatkowe zmysły i narządy.

Etapem przejściowym pomiędzy człowiekiem a postczłowiekiem jest „transczłowiek” (»transhuman«). Termin »transhuman« pochodzi od »transitional human« (człowiek przejściowy) i został ukuty przez Ferejduna M. Esfandiary (1930-2000), podpisującego się w swoich futurystycznych tekstach jako FM-203019. Transludzie mają się charakteryzować używaniem protez i dokonywaniem operacji plastycznych, intensywnym wykorzystywaniem technologii komunikacyjnych, mają być kosmopolitami i ateistami, odrzucającymi tradycyjne wartości rodzinne i społeczne. Charakteryzuje ich ponadto

18 Nawiązuję tym do tytułu znanej książki Francisa Fukuyamy (ur. 1952), w której opisuje on w czarnych barwach konsekwencje planowanej przez transhumanistów rewolucji biotechnologicznej, zob. F. F u k u y a m a, Koniec człowieka. Konsekwencje rewolucji biotechnologicznej, (tłum.) B. Pietrzyk, Kraków 2004.

19 F M-2030 (F e r e i d ou n M. E s fand i a r y), Are You a Transhuman?: Monitoring and Stimulating Your Personal Rate of Growth in a Rapidly Changing World, New York 1989, s. 42. 
mobilny tryb życia oraz korzystanie $\mathrm{z}$ techniki in vitro $\mathrm{w}$ prokreacji (gdyż zazwyczaj będą żyć w pojedynkę).

Trudno nie zauważyć, że to ujęcie ,transczłowieka” jest bardzo bliskie postmodernie, co wskazuje na daleko posunięte pokrewieństwo ponowoczesności i transhumanizmu. Bardzo podobne też wydaje się podejście do etyki, gdyż - jaki pisał cytowany już Nick Bostrom -

„W przeciwieństwie do wielu innych perspektyw etycznych, które w praktyce często wykazują reakcyjne podejście do nowych technologii, pogląd transhumanistyczny kieruje się rozwijającą się wizją, która ma bardziej proaktywne podejście do polityki technologicznej. Ta wizja, w szerokim ujęciu, ma na celu stworzenie możliwości dłuższego i zdrowszego życia, zwiększenia pamięci i innych zdolności intelektualnych, udoskonalenia naszych emocjonalnych reakcji i zwiększenia naszego dobrego samopoczucia, i generalnie osiągnięcia większego stopnia kontroli nad własnym życiem. Ta afirmacja ludzkich możliwości jest oferowana jako alternatywa dla zwyczajowych nakazów «zabawy w Boga», «zadzierania z naturą», «manipulowania istotą człowieka», czy okazywania «karygodnej pychy»" ${ }^{20}$.

Jasne jest zatem dlaczego zarzuty występowania przeciw naturze, Bogu, dobru wspólnemu narodu lub społeczeństwa kierowane wobec

20 N. B o s t ro m, Transhumanist Values, dz. cyt., s. 4: „In contrast to many other ethical outlooks, which in practice often reflect a reactionary attitude to new technologies, the transhumanist view is guided by an evolving vision to take a more proactive approach to technology policy. This vision, in broad strokes, is to create the opportunity to live much longer and healthier lives, to enhance our memory and other intellectual faculties, to refine our emotional experiences and increase our subjective sense of well-being, and generally to achieve a greater degree of control over our own lives. This affirmation of human potential is offered as an alternative to customary injunctions against playing God, messing with nature, tampering with our human essence, or displaying punishable hybris". 
transhumanistów i podzielających niektóre ich idee liderów ruchów LGBT, stanowią dla nich samych wyłącznie potwierdzenie obranych przez nich celów. Chodzi im bowiem właśnie o przekroczenie natury ludzkiej w kierunku postludzkim, eliminację wszelkiej religii, jako totalnej metanarracji, afirmację dobra indywidualnej jednostki przeciw opresji społecznej, państwowej lub narodowej.

Poglądy transuhumanistów najczęściej, i słusznie, kojarzone są z ujęciami Fryderyka Nietzschego (1844-1900). Teresa Grabińska nawet termin posthuman tłumaczy jako „nadczłowiek”21. Sami transhumaniści - o czym już wspomniano - odwołują się do humanizmu renesansowego, a Rafał Tichy wskazuje na chrześcijańskie korzenie transhumanizmu i to pomimo tego, że zwolennicy tej ideologii radykalnie odżegnują się od wszelkiej religii, a od chrześcijaństwa przede wszystkim. Warto może chwilę zatrzymać się nad ujęciem Tichego, gdyż zdaje się ono potwierdzać wyrażoną we wstępie tezę Mieczysława Gogacza, że to platonizm i arystotelizm stanowią pierwsze i podstawowe paradygmaty ludzkiego myślenia, a wszystko inne - filozofie, teologie, ideologie są wobec nich wtórne. Tichy bowiem pisze,

„że w swojej krytyce praw natury transhumaniści są w wielu aspektach bliżsi właściwie rozumianym zasadom chrześcijańskiej antropologii, niż współcześni konserwatyści twardo broniący ich niezmienności, którzy zbliżają się przez to do antropologii opartej na zasadach filozofii greckiej. Chrześcijańscy konserwatyści - dodaje - broniący do ostatniego tchu godności i wspaniałości ludzkiej natury stworzonej przez Boga, zapominają bowiem, że chrześcijańska wizja człowieka z samej swej istoty jest transhumanistyczna. To właśnie

${ }_{21}^{21}$ T. G r a b i ń s k a, Zagrożenia bezpieczeństwa społecznego wideologii transhumanizmu, „Kultura Bezpieczeństwa. Nauka - Praktyka - Refleksje”, 18 (2015), s. 53. 
swoim transhumanizmem - stwierdza - myśl ta od samego początku swego formowania się przełamywała grecki naturalizm"22.

Ten naturalizm grecki, nazywany przez Tichego „archaicznym”, swoje ukoronowanie znajduje w metafizyce i antropologii Arystotelesa ${ }^{23}$, „genialną” próbę jego „przekroczenia” znajdujemy zaś w pismach Platona ${ }^{24}$. Wynika z tego dalej, że „konserwatystami” są wszyscy ci, którzy odwołują się do „archaicznych” poglądów Arystotelesa, natomiast ,właściwie rozumiane zasady antropologii chrześcijańskiej” stanowią kontynuacje ,genialnych” intuicji Platona. Takie postawienie sprawy (wraz z politycznej proweniencji epitetem „konserwatyzmu”, wzmocnionym „,archaicznością”) właściwie przynajmniej na terenie chrześcijaństwa - powinno zamykać dyskurs. Tymczasem - jak to zwykle bywa - znajdują się ludzie, którzy chcą pozostać archaicznymi konserwatystami i nie spieszno im do „nowego wspaniałego świata" 25 bez względu na to czy ma on być posthumanizmem, czy „przebóstwieniem”26. Boecjusz (480-525), Albert Wielki (1193/1205-1280), Tomasz z Akwinu (1224/25-1274) przeciwni są tezie o „transformacji” bytów ludzkich, gdyż formę

22 R. T i c hy, Gwiazdy naszym przeznaczeniem, art. cyt., s. 7.

23 Tamże, s. 9.

24 Tamże, s. 10. Jeśli się jednak zważy, że Platon (427-347) jest starszy od Arystotelesa (384-322), to wypadałoby platonizm uznać za myśl jeszcze bardziej ,archaiczną" niż arystotelizm.

25 Nawiązuję tu do tytułu książki Aldousa Huxleya (1894-1963), będącej pastiszem, zaliczanym do gatunku ,antyutopii”, na technokratyczne wizje społeczeństwa, bliskie wielu ideom transhumanistów, zob. A. H u x le y, Nowy wspaniały świat, (tłum.) B. Baran, Warszawa 2011 (sama książka, co ciekawe, ma być plagiatem dwóch wcześniejszych polskich powieści pióra Mieczysława Smolarskiego). Na zbieżności opisów Huxleya z postulatami transhumanistów ciekawie zwraca uwagę Kamil Szymański, zob. K. S z y m a ń s k i, Transhumanizm, „Kultura i Wartości”, 13(2015), s. 150.

26 Tamże, s. 20-23. 
pojmują po arystotelesowsku, jako „tego, co niezmienne, tego, co (...) zakreśla stałe granice ich doskonałości"27.

Wydaje się bowiem, że tak dawniej jak i dzisiaj, na terenie chrześcijaństwa ścierają się dwie wizje rzeczywistości - platońska i arystotelesowska - a w konsekwencji także termin ,forma” jest inaczej rozumiany przez różnych teologów chrześcijańskich. Dla Tomasza z Akwinu forma jest aktem istoty bytu, określa jego stałą tożsamość, która nie podlega zmianom i dzięki temu może stanowić podstawę określenia tego, czym dany byt jest (quidditas). Takie terminy jak formatio (formowanie), deformatio (defomowanie), transformatio (transformacja), reformatio (reformowanie) odnoszą się do rozumienia formy jak kształtu czegoś - ciała człowieka, jego osobowości, religijności, słowem zespołu cech (przypadłości), nie zaś jego istoty. W tej konwencji wychowanie (a także jego skutek) nazywa się ,formacją", a przekształcenia różnych instytucji , a nawet obyczajowości - ich „reformami” (językowym reliktem takich „reform” jest nazwa części damskiej bielizny, wprowadzona w wyniku takowych na pocz. $\mathrm{XX}$ w.). Jest chyba dla wszystkich jasne, że zupełnie czym innym jest arystotelesowska forma i forma desusów, która w wyniku reformy uległa zmianie. Mówiąc więc „forma” realiści i idealiści mówią zupełnie o czym innym. Nie można więc powiedzieć, że taki np. Bernard z Clairvaux jest zwolennikiem zmienności istoty człowieka (której fundamentem jest akt formy), gdyż mówiąc o transformacji człowieka nie ma on na pewno na myśli formy pojętej po arystotelesowsku.

27 Tamże, s. 9. W 1277 r. poglądy filozoficzne i teologiczne, budowane na myśli arystotelesowskiej zostały obłożone kościelnymi potępieniami z inspiracji augustynizujących teologów, którzy przez historyków nazywani są „,konserwatystami”, w 2017 r. konserwatystami nazywa się zwolenników metafizyki Arystotelesa, przeciwstawiając ich postępowym idealistom. W tej sytuacji można zapytać, czy tomiści (podzielający za Arystotelesem przekonanie o niezmiennej istocie człowieka) są konserwatywni czy postępowi? Wydaje się więc, że używanie określeń dobrych może w polityce i działalności społecznej jest całkowicie anachroniczne w odniesieniu do historii filozofii lub teologii. 
Odpowiedzią ze strony „Rezerwatu” ${ }^{28}$ na antropologiczne pomysły transhumanistów (celowo nie piszę o „antropologicznej wizji”, bo takowej nie ma, ale o tym nieco niżej) może być antropologia personalistyczna, co trafnie proponuje przywoływana już Teresa Grabińska. Uważa ona, że

„arystotelesowska etyka środka, która leży u filozoficznych podstaw etyki personalistycznej jest wypełnieniem (...) eudajmonizmu. Człowiek szczęśliwy (spełniony) w rozumieniu Arystotelesa to ten, który potencjalnie może osiągnąć pełnię szczęścia $\mathrm{w}$ przeświadczeniu o pełni dóbr, jakie posiadł, a określenie owej pełni dyktuje pełnia cnót (sprawności, dzielności moralnych, rozumianych jako wyrozumowane sposoby umiarkowanego działania), które sam w swym życiu wypracował. W stanie owej doskonałości moralnej nie odczuwa braku, niezależnie od warunków obiektywnych, w jakich się znajduje; to w owej pełni doskonałości staje się naturalnym darem dla innych, wpisuje się w dobro wspólne i sam $\mathrm{w}$ relacjach $\mathrm{z}$ innymi jest wspomagany $\mathrm{w}$ utrzymaniu owej pełni” ${ }^{2}$.

Relacje z innymi przez miłość i przyjaźń, wypełnianie własnej osobowości przez nabywanie sprawności i cnót - wiedzy, mądrości, umiejętności (ars), roztropności, umiarkowania, sprawiedliwości, męstwa (że wymienimy najważniejsze), zaangażowanie w rozwój wspólnot od rodziny po naród, stanowią jądro uszczęśliwiającej działalności człowieka, który swoją wiedzą i pomysłowością zaradza potrzebom i ograniczeniom, wynikającym tak z cielesności człowieka jak i charakteru jego duchowości. Dlatego potrzebna jest ochrona

28 W książce Huxleya Rezerwat jest miejscem na jego obrzeżach, gdzie mogą przebywać ci, którzy nie chcą żyć w „nowym wspaniałym świecie”.

${ }_{29}$ T. G r a b i ń s k a, Zagrożenia bezpieczeństwa społecznego $w$ ideologii transhumanizmu, art. cyt., s. 67. 
zdrowia i edukacja, środki transportu i media komunikacyjne, maszyny i urządzenia oraz muzyka, kultura i sztuka. Nie powinno być jednak tak, że to, co z istoty swej jest środkiem do czegoś, np. komunikacja, stało się celem samym w sobie. Pociągi, które wożą tylko powietrze, nie są - jak celnie zauważył pewien polski były premier - nikomu potrzebne.

Tymczasem rozwój technologii, w tym technologii biomedycznych, jest dla transhumanitów celem nadrzędnym, który nie powinien być w żaden sposób kontrolowany. Kamil Szymański w swoim artykule o transhumanizmie słusznie pisze, że:

„Transhumaniści twierdzą, że powinniśmy jakby »bezkrytycznie« przyjmować wszelkie możliwe udoskonalenia, które oferują nam inżynierowie. Wszystkie urządzenia, które powstają, służą ulepszaniu życia i dlatego nie powinniśmy się zastanawiać nad sensem ich powstawania, lecz z nich korzystać" 30 .

Takie postawienie sprawy, oprócz niewątpliwej absolutyzacji rozwoju techniki i technologii, prowadzi transhumanistów do niemożności nakreślenia wizji postczłowieka. Może on być bowiem programem, sztuczną inteligencją, ,awatarem” lub cyborgiem, ale może zachować część swej „,biologii”, z tym że z licznymi modyfikacjami biotechnologicznymi lub zmienionym DNA - zależy to od rozwoju nauk i decyzji samych postludzi, mających do wyboru wiele możliwości, których my nawet nie jesteśmy w stanie się domyślać. Nick Bostrom w swoim zbiorze pytań i odpowiedzi na temat transhumanizmu pisze, że brakuje nam wiedzy, jaki będzie postczłowiek i jak ukształtuje on posthumanistyczną rzeczywistośćc ${ }^{31}$. „Jest to zarazem logiczna, jak i wymijająca odpowiedź”, pisze w innym

30 K. S z y m a ń s k i, Transhumanizm, art. cyt., s. 136.

31 N. B o s tro m, The Transhumanist FAQ, version 2.1, Oxford 2003, s. 6. 
artykule Kamil Szymański ${ }^{32}$. Zawsze bowiem można powiedzieć, że człowiek nie rozumie świata postludzkiego, bo go jeszcze nie ma. Uchyla to każdą krytykę, zarazem jednak powoduje uchylenie naukowego charakteru transhumanizmu, o który jego twórcy tak bardzo zabiegają. Skoro bowiem nie ma możliwości falsyfikacji jakieś teorii, to zgodnie z falsyfikacjonizmem Karla Poppera nie można przypisać transuhumanizmowi statusu teorii naukowej ${ }^{33}$.

Jedno wszakże dla transhumanistów jest pewne: człowiek stanie się kimś innym, ulegnie gatunkowej przemianie, nie będzie już tym, kim jest teraz. Przy czym w „klasycznym” transhumanizmie ten człowiek ma wyłącznie wymiar materialny, jest wyłącznie organizmem, którego elementem składowym jest mózg tego typu, że daje świadomość, możliwość stawiania problemów filozoficznych i pozwala na rozwój nauki i techniki (czym różni się np. od mózgu szympansa). Wszystkie - niekiedy bardzo fantastyczne - pomysły transhumanistów dotyczą w gruncie rzeczy tych dwu sfer: organizmu i świadomości, przy czym świadomość jest nieodłącznie funkcją mózgu. Ten redukcjonizm jest podstawą krytyki transhumanizmu w przywoływanych już książkach Huxleya i Fukuyamy.

$Z$ tego punktu widzenia nieco tylko odmienny jest ,transhumanizm chrześcijański”, opisywany przez Rafała Tichego, choć skutek jest ten sam - „,koniec człowieka” i (przynajmniej w założeniu) początek czegoś lepszego. „Transhumanizm chrześcijański” widzi swój cel w ,przebóstwieniu” człowieka, które ma zmienić go w jakąś bosko-ludzką hybrydę o cechach bardzo zbliżonych do transuhumanistycznego postczłowieka. Jeden i drugi transhumianizm są pochodną idealistycznej myśli platońskiej, gdzie ,rzeczywistość, którą jesteśmy i otaczające nas rzeczy, to... tylko relacje. Zarazem jest to ich całość stanowiąca świat rzeczy materialnych i odbitek idei"34. Tymczasem - według Mieczysława Gogacza - „błędem metafizycznym jest ujmo-

32 K. S z y m a ń s k i, Transhumanizm: utopia czy ekstropia? „Idea. Studia nad strukturą i rozwojem pojęć filozoficznych", 27(2015), s. 166.

33 K. S z y m a ń s k i, Transhumanizm, art. cyt., s. 148.

34 M. G o g a c z, Platonizm i arystotelizm, dz. cyt., s. 6. 
wanie bytów jako zespołu relacji, pogląd, że tylko relacje wypełniają byt i stanowią świat"35. W ujęciu Arystotelesa - wyjaśnia dalej -

„byty są tym, czym są. Owszem, występują w uwarunkowaniach i relacjach. To jednak świadczy tylko o tym, że są najpierw czymś w sobie, że warunki i relacje, zawsze zewnętrzne, nie stanowią ich istoty. Będąc tym, czym są, byty nawiązują relacje i są poznawane"36.

Różnica między ujęciem platońskim i arystotelesowskim zasadza się na tym, że w tradycji platońskiej to, co bezpośrednio ujmujemy, poznając jakiś byt, uznajemy od razu za istotę tego, co poznajemy i ewentualnie szukamy dlań przyczyn zewnętrznych (idei). Arystoteles zalecał, aby dla tego, co bezpośrednio ujmujemy szukać najpierw przyczyny w poznawanym bycie. $\mathrm{W}$ ten sposób byt jawił się mu jako to, co formowane (materia) i to, co formujacee (forma). Forma jest tu aktem, a materia możnością. Z tego punktu widzenia mówienie, że człowiek jest „formowany” stanowi zredukowanie bytu ludzkiego do materii, która jest właśnie tym, co formowane. Twierdzenie, że teza o „formowalności” człowieka, pociągającej za sobą zmianę tego, kim jest, nie jest żadnym przezwyciężeniem arystotelesowskiego „archaicznego naturalizmu”, lecz powrotem do stanowiska Platona i platoników. W stanowisku tym człowieka określa zespół cech - ich zmiana owocuje zmianą podmiotu. Dla Arystotelesa przypadłości nie są w stanie zmienić istoty bytu - nawet więc bardzo radykalna zmiana przypadłości i relacji nie zmienia ich podmiotu. I w tym tkwi zasadnicze nieporozumienie transhumanizmu - nawet bardzo radykalna zmiana własności człowieka, w kierunku „cyborgizacji” lub „ubóstwienia” nie spowoduje zmiany podmiotu: będzie nim nadal człowiek - „scyborgizowany” lub „ubóstwiony”. Wszystko to bowiem, „cyborgizacja” i „ubóstwienie” to skutek przypadłości i relacji - także relacji osobowych z Bogiem, które przemieniają

\footnotetext{
35 Tamże, s. 28.

36 Tamże, s. 30.
} 
osobowość człowieka na miarę uwielbienia, które Bóg ma dla człowieka zgodnie z obietnicą Psalmu 90: erípiam eum, et glorificábo eum (,ocalę go i go uwielbię") 37 .

Podobnie rzecz się ma w odniesieniu do osobowego charakteru bytu ludzkiego. Dla „tradycji realistycznej (...) każdy człowiek jest osobą od momentu poczęcia" ${ }^{38}$. Natomiast ,przedstawiciele tradycji idealizmu filozoficznego twierdzą, że człowiek nie rodzi się jako osoba, lecz że dopiero staje się nią w procesie tzw. personalizacji lub humanizacji" "39. Barbara Kiereś surowo ocenia takie ujęcie pisząc, że „to stanowisko jest pokłosiem oderwania antropologii od jej realistycznej bazy, jaką jest konkretny człowiek i budowania

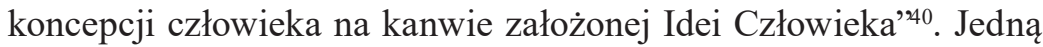
z konsekwencji tego idealizmu jest ,pomieszanie teorii osoby z teorią osobowości'"41, co często prowadzi do prostego utożsamienia osoby z osobowością. Tymczasem, jak trafnie pyta Autorka, co w takim wypadku jest przyczyną i podmiotem osobowości? Przyjmując idealistyczną koncepcję człowieka osoby musimy stwierdzić, że tym podmiotem jest co najwyżej relacja do idei: pomysłu, koncepcji, projektu. Człowiek i osoba, w tym co bezpośrednio ujmujemy, jest luźnym zespołem cech, własności, relacji, świadomości. Scala je właśnie odniesienie do idei. Taka wydaje się właśnie być koncepcja człowieka w transhumanizmie, czego zresztą transhumaniści nie ukrywają, i wobec tego zmiana w obrębie cech powoduje dla nich istotową (,gatunkową”) zmianę człowieka. Różnić się może jedynie punkt odniesienia - owa idea człowieka, która zazwyczaj jest jakoś

37 Ciekawie o tym pisze w swoim artykule (po słowacku) Pavol Dancák, zob. P. D a n c á k, Personalizmus a paideia, spoločné wýchodiská a ciele, w: P. D a n c á k (red.), Presonalizmus v procese humanizácie l’udskej spoločnosti, Prešov 2014, s. $46-59$.

38 B. K i e r és, Personalizacja człowieka-odosobydo osobowości, w: P. D a n c á k (red.), Presonalizmus v procese humanizácie l’udskej spoločnosti, Prešov 2014, s. 210 .

\footnotetext{
39 Tamże.

40 Tamże.

41 Tamże, s. 211.
} 
formułowana, np. w najbardziej popularnym transhumanizmie Bostroma, ukryta w zabsolutyzowanym rozwoju nauki i techniki.

\section{ZAGROŻENIE CZYHAJĄCE NA CZLOWIEKA POSTMODERNY I TRANSHUMANIZMU}

Ponowoczesność, a jeszcze bardziej transhumanizm, to „projekty" mniej lub bardziej zaawansowane w realizacji. Ich punkty dojścia są czasem przedmiotem naukowych dociekań, ale częściej bywały domeną fantastyki naukowej. Podobnie i ich krytyka zawarta była w literaturze speculative fiction - jak wspominana już książka A. Huxleya czy słynny Rok 1984 George'a Orwella ${ }^{42}$. Jednakże w miarę realizacji „,postmodernistycznego projektu” zaczęli się jego skutkom przyglądać socjologowie (często „filozofujący”, jak Zygmunt Bauman ${ }^{43}$ ). Z ich obserwacji Urszula Wolska (ur. 1952) wyprowadza pewną „wizję człowieka ponowoczesnego”, która wydaje się bardziej spełnieniem przewidywań krytyków postmodernizmu i transhumanizmu niż spełnieniem ich marzeń. „Lekarstwem”

42 G. O r w e 11, Rok 1984, (tłum.) T. Mirkowicz, Warszawa 2013.

43 Zob. Z. B a u m a n, Dwa szkice o moralności ponowoczesnej, Warszawa 1994, Tenże, Wspólnota, (tłum.) J. Margański, Kraków 2008, a przede wszystkim: Tenże, Płynna nowoczesność, (tłum.) T. Kunz, Kraków 2007 i cała seria kontynuacji głównej tezy o „płynności” współczesnej kultury: Tenże, 44 listy ze świata płynnej nowoczesności, (tłum.) T. Kunz, Kraków 2011; Tenże, Płynne życie, Kraków 2007; a zwłaszcza: Tenże, Życie na przemiał, Kraków 2006. Co ciekawe, autor (żyjący w latach 1925- 2017) osobiście z entuzjazmem uczestniczył w urządzaniu w Polsce „nowego wspaniałego świata”, będąc funkcjonariuszem stalinowskiej bezpieki w latach 1945-1953 i do końca długiego życia nie zweryfikował swoich ówczesnych decyzji mówiąc, że ,idee komunistyczne były po prostu kontynuacją oświecenia” (za: P. G o n t a r c z y k, Nowe kłopoty z historia. Publicystyka z lat 2005-2008, Warszawa 2008, s. 74). Nie przeszkadzało mu to potem (przynajmniej w teorii) być ostrym krytykiem m. in. tego, co wprowadzał w Polsce. Nie przeszkadzało to także różnym środowiskom naukowym i nawet kościelnym w niemal bałwochwalczym uwielbianiu Baumana, jako jednego z twórców pojęcia postmodernizmu, np. 18 września 2016, uczestniczył na zaproszenie papieża Franciszka w 30. ekumenicznym spotkaniu w Asyżu i wygłosił na nim wykład. 
na to ,zło nękające współczesnego człowieka" ${ }^{\text {"4 }}$ może być według niej tomistyczna teoria osoby. Urszula Wolska pisze, że podstawą wspomnianej wizji jest zasada Paula Feyerabenda: anything goes -,wszystko jest dozwolone", a

„człowiek postmoderny, «projektowany» i/lub realizujący doktrynę postmodernistyczną, jest ujmowany fragmentarycznie, materialistycznie, traktowany jak każda inna rzecz w przyrodzie i na globalnym konsumenckim rynku, jako przedmiot, rzecz, narzędzie i środek do uzyskania jak największej korzyści i przyjemności. Stara się po prostu dopasować do tego świata, zmieniając tożsamość, osobowość, obrabiając się wewnętrznie i zewnętrznie na wszystkie możliwe sposoby, by jak najlepiej zaprezentować się na globalnym rynku, wybiera też często nowy styl życia w pojedynkę, bycie «singlem»" 45 .

Tych osobowości (za Z. Baumanem) można wymienić kilka: „spacerowicza" (który z nikim się nie wiąże, tylko obserwuje innych, pozostając w cieniu), „włóczęgi” (który ciągle zmienia miejsce pobytu, zawsze nie zadowolony z tego, co znalazł) „gracza” (którego pasją jest podejmowanie ryzyka, a spełnieniem wygrana, często za wszelką cenę), ,turysty” (który podróżuje w celu zdobywania nowych wrażeń i robienia dokumentacji, a nie z wewnętrznego przymusu, jak włóczęga. Zwykle ciężko pracuje aby zaraz potem wydać wszystkie zarobione pieniądze na coraz bardziej egzotyczne podróże). Nakłada się na to model życia w pojedynkę, charakteryzujący przede

44 U. W ol s k a, Wizja człowieka ponowoczesnego a tomistyczna teoria osoby, „Rocznik Tomistyczny”, 4(2015) s. 191-214. Autorka w swoim artykule świadomie nawiązuje do wykładu doktorskiego (podczas uroczystości nadania doktoratu honoris causa KUL Giovanniego Reale w 2001 r.), zob. Por. G. R e a l e, Zło nękajace współczesnego człowieka i lekarstwo, które można na nie znaleźć w myśli antycznej, (tłum.) E. I. Zieliński, „Ethos”, 14(2001) nr 56, s. 15-39.

45 U. W ol s k a, Wizja człowieka ponowoczesnego a tomistyczna teoria osoby, art. cyt., s. 194. 
wszystkim „młodych, wykształconych z wielkich miast”46, którzy nie tworzą trwalszych wspólnot, lecz jedynie tymczasowe i niezbyt trwałe grupy (cyklistów, biegaczy, rolkarzy). „Ethan Watters - pisze Wolska - nazywa ich plemionami miejskimi - urban tribes. Łączy ich jedynie podążanie za modnym stylem bycia singlem, bezwzględne nastawienie na karierę i aktywność zawodową, która umożliwia im konsumowanie modnych luksusowych dóbr, modne i drogie aktywne spędzanie wolnego czasu, oraz w tym samym stylu aktywność społeczna i towarzyska"47. W polskiej publicystyce politycznej nazwano ich lemingami, natomiast wydaje się, że mamy tu do czynienia z jakąś postacią transczłowieka, opisywaną przez Bostroma ${ }^{48}$.

Urszula Wolska w swoim artykule na podstawie literatury przedmiotu zestawia sześć negatywnych zjawisk ,nękających człowieka postmoderny" ${ }^{99}$. Jako pierwszy z nich za Giovannim Reale wymienia praktyczny nihilizm, polegający na ,rozchwianiu, dysolucji i eliminacji wszelkich wartości” i inicjujący przez to ,procesy zniszczenia i samozniszczenia" człowieka. Kolejnym zagrożeniem, a nawet źródłem zagrożeń, jest scjentyzm. Powierzenie bowiem naukom szczegółowym, których przedmiot badań z istoty jest fragmentaryczny i wybitnie aspektowy, dostarczania odpowiedzi na temat istoty życia, istoty człowieczeństwa, doprowadza do „materializacji, fragmentaryzacji oraz utylitaryzacji człowieka i świata”. Powoduje to zanegowanie podmiotowości człowieka, a wyeksponowanie jego irracjonalnej emocjonalności oraz cielesności z silnym akcentem na seksualność. Wszystkiemu temu towarzyszy porzucenie moralności i praktyczne uprzedmiotowienie człowieka, podobnie jak coraz bardziej zauważalny kryzys ludzkiej tożsamości - wyróżniony jako trzecie „negatywne zjawisko” postmodernizmu. Mówi się już nawet

\footnotetext{
46 Nawiązanie do określenia elektoratu pewnej nowoczesnej i „europejskiej” partii w Polsce.

$47 \mathrm{U} . \mathrm{W}$ ol s k a, Wizja człowieka ponowoczesnego a tomistyczna teoria osoby, art. cyt., s. 195.

48 Por. N. B o s t r o m, The Transhumanist FAQ, dz. cyt., s. 6-7.

49 U. W ol s k a, Wizja człowieka ponowoczesnego a tomistyczna teoria osoby, art. cyt., s. 197-204.
} 
o homo actualis - człowieku o zmiennej tożsamości, dostosowywanej do „tu i teraz” „płynnego” świata, którego symbolem jest „,człowiek bez właściwości” ze słynnej powieści Roberta Musila (1880-1942) ${ }^{50}$. Destrukcyjny charakter tego rozmycia tożsamości zauważają myśliciele z bardzo różnych środowisk ideowych, np. Scott Lash pisze, że ,postmodernistyczna wielość i różnica jest narzędziem dekonstrukcji tożsamości”, a Giorgio Agamben dodaje, że ,identyfikowani na podstawie odcisków palców oraz kodów genetycznych, tracimy osobowość" ‘5 . Na to nakłada się (jako kolejne negatywne zjawisko) infantylizacja kultury, o czym Hannah Arendt pisała już w drugiej połowie XX w. Mechanizm tego zjawiska polega na „urynkowieniu” kultury przez co redukuje się ona do masowej, nieustannej rozrywki, nazywanej ,zabawą na śmierć”. Doskonale możemy to obserwować na przykładzie polskich mediów elektronicznych, utrzymujących się w głównej mierze z reklam. Ceny czasu reklamowego zależą od „oglądalności” programu, w ramach którego (przed lub w trakcie) emitowane są reklamy. Podnoszenie owej „oglądalności” prawie zawsze polega na uproszczeniu (żeby nie powiedzieć: sprymitywizowaniu) treści programu, tak aby zadowolić coraz mniej wybredne gusta „masowego" widza lub słuchacza. To „cashowanie contentu” (jak się mówi w mediach) stanowi samonakręcającą się spiralę w dół, w wyniku której mamy to, co mamy. Wolska przywołuje w tym kontekście słowa Frederika Jamesona, który napisał, że

„postmodernizm uległ fascynacji całym tym «zdegradowanym» pejzażem tandety, kiczu i seriali telewizyjnych i kultury «Reader's Digest», reklam i moteli, nocnych programów telewizyjnych i hollywoodzkich filmów klasy B oraz tak zwanej paraliteratury, z jej lotniskowymi

50 R. Mu s i 1, Der Mann ohne Eigenschaften, pisana w latach 1921 - 1942, w części wyd. w 1930, polska wersja: R. M u s i 1, Człowiek bez właściwości, (tłum.) K. Radziwiłł, K. Truchanowski, J. Zeltzer, wyd. 1, Warszawa 1971 (wyd. 2, Warszawa 2000-2002).

51 Przytaczam te cytaty za omawianym artykułem Urszuli Wolskiej. 
podziałami na horror i romans, popularne biografie, powieści kryminalne oraz science fiction i fantasy".

Autorka omawianego artykułu zauważa, że wszystkie te zjawiska mają swoje głębsze dno o charakterze ,,pierwszej przyczyny”. Jest nią cywilizacja nadmiaru i braku, czyli jak pisze „twierdze bogatych i getta biednych". Współczesny bowiem świat (świat późnego kapitalizmu) charakteryzuje się radykalnym pogłębianej różnic majątkowych. W 2016 r. 1 procent najbogatszych stał się właścicielem ponad połowy wszystkich dochodów świata i proces ten się pogłębia. W jego wyniku (winner takes all - „zwycięzca bierze wszystko”) obserwujemy „ugettowianie”, czyli skupienie na bardzo małych obszarach ogromnych rzesz ludzi (tzw. „,nowa bieda”). „Ludzie śmieci” nie odnoszą żadnych korzyści z bogactwa elit - koncepcja „,skapywania bogactwa” nie zafunkcjonowała, a nierówności społeczne pogłębiane są przez kryzysy finansowe ostatnich lat, w których zyski są prywatyzowane, a straty nacjonalizowane. „Wygoda i luksus - podkreśla Wolska czyli nadmiar u jednych oraz ubóstwo i wykluczenie społeczne, czyli brak u innych, ostatecznie degradują i degenerują oraz sprawiają, że człowiek zatraca swoją ludzką godność i to zarówno ten biedny jak i ten bogaty”. To ostatnio wiąże się bezpośrednio z ,pogarszającą się kondycją duchową ponowoczesnego człowieka" (zjawisko szóste). Zaburzenia psychosomatyczne jak lęki, bezsenność, depresje i nierozpoznany niepokój oraz ogólne rozbicie dotyczą według raportu WHO z 2001 r. już jednej czwartej ludzkości. W krajach rozwiniętych ten odsetek jest jeszcze większy. To zjawisko dotyczy także w coraz większym stopniu naszego kraju. Problemy z określeniem własnej tożsamości i swego miejsca w świecie oraz zanikanie więzi rodzinnych i społecznych uważane są za główne czynniki sprzyjające tym zjawiskom.

Urszula Wolska w tomistycznej teorii osoby widzi „lekarstwo” na bolączki człowieka postmoderny ${ }^{52}$ :

52 U. W ol s k a, Wizja człowieka ponowoczesnego a tomistyczna teoria osoby, art. cyt., s. 212 . 
1. Podmiotowe, osobowe i duchowe ujęcie człowieka można przeciwstawić skrajnemu scjentyzmowi, nihilizmowi, między innymi przedmiotowemu, utylitarnemu wykorzystaniu człowieka dla korzyści i przyjemności. Człowiek, jako przedmiot, produkt, rzecz, narzędzie i środek jest wykorzystywany wbrew swojej naturze i godności.

2. Osobowe bycie sobą może być drogą do poznania siebie i przezwyciężenia pogłębiającego się kryzysu tożsamości.

3. Podkreślenie godności osoby ludzkiej i troska o wspólne dobro jest próbą wyjścia z cywilizacji nadmiaru i braku - twierdz bogatych i gett wykluczonych. Maksymalizacja zysku bez maksymalizacji dobra nie ma żadnego sensu ani pożytku dla ludzi.

4. Postmodernistyczna kultura jest depersonalistyczna, jednak tylko personalistyczny wymiar kultury z kulturą chronienia osób może być sposobem na zahamowanie zjawiska infantylizacji kultury i tym samym człowieka.

5. Nawiązanie relacji osobowych i troska o drugiego może zahamować zjawisko rozpadu więzi międzyludzkich, samotności i utraty poczucia bezpieczeństwa oraz może wpłynąć na poprawienie się pogarszającej się kondycji duchowej ponowoczesnego człowieka.

6. Postępującą cywilizację śmierci, gdzie człowiek uzurpuje sobie prawo i stanowienie prawa do ingerencji w proces poczęcia, rozwoju i terminacji życia człowieka, praktycznie w każdym jego momencie, można zastąpić cywilizacją miłości. Miłość to umiłowanie życia, chronienie go od poczęcia aż do naturalnej śmierci, to myślenie dobrze o drugim i staranie się o jego dobro.

Nikt chyba nie neguje pozytywnych skutków rozwoju nauki i techniki w postaci znacznego wydłużenia życia człowieka, radykalnego ograniczenia umieralności dzieci, zwiększenia i potanienia produkcji żywności, ułatwienia codziennego życia, komunikacji, kontaktów, zdobywania wiedzy i wielu innych udogodnień w każdej niemal dziedzinie. Mają bowiem rację ci, którzy piszą, że przeciętny 
człowiek w rozwiniętych państwach w XXI wieku żyje lepiej niż król pięć wieków temu. Podróżuje szybciej i wygodniej, uzyskuje sprawniej informacje i jeszcze sprawniej komunikuje się z innymi. Nawet w dziedzinie kultury dysponuje zasobami, o których szesnastowieczny władca nie mógł nawet pomarzyć: może np. słuchać muzyki jakiej tylko zapragnie nie będąc skazanym na repertuar i umiejętności dworskiej orkiestry. To są niepodważalne sukcesy. Ważne jest jednak, aby pomimo tej technicznej wielkości duchowo nie pozostać karłem. Papież Paweł VI wyraził to za pomocą słynnego czwórmianu „cywilizacji miłości”" ${ }^{3}$ : Prymat etyki przed techniką, prymat osoby nad rzeczą, prymat być nad mieć, prymat miłosierdzia przed sprawiedliwością. Przyjęcie tych, wydawałoby się akceptowalnych zasad, może napotykać jednak trudności, gdyż etyka postmodernizmu i transhumanizmu niektórym z nich sprzeciwia się świadomie i wprost, jak choćby konieczności kontrolowania rozwoju techniki za pomocą norm moralnych, o czym wspomniano już w tym artykule ${ }^{54}$.

$$
* * *
$$

Rozpoczęliśmy te rozważania stwierdzeniem, że nie da się uciec od pytań metafizycznych, gdyż ich stawianie wynika z faktu rozumności człowieka i wcześniej lub później prawie każdy z nas interesuje się tym, kim jest, dlaczego istnieje i po co? Są to pytania par excellence metafizyczne, tymczasem - jak słusznie zauważa jeden z czołowych polskich metafizyków Andrzej Maryniarczyk (ur. 1950) - „całość współczesnego poznania chce się usytuować w opozycji do poznania metafizycznego"55. Chodzi więc o to, aby oduczyć ludzi stawiania tych „naturalnych” pytań. Sposobem na wprowadzenie tego zabiegu jest zastąpienie poznania prawdy przekonaniami,

53 W homilii na Boże Narodzenie w 1975 r.

54 Zob. też. A. A n d r z e j u k, Etyka chronienia osób. Zarys problematyki, „Rocznik Tomistyczny”, 3(2014), s. 23-41.

55 A. M a r y n i r c z y k, Cóż po filozofii św. Tomasza z Akwinu w czasach postmetafizycznych? ,Rocznik Tomistyczny”, 3(2014), s. 11. 
a filozofii - światopoglądem, a w dalszej perspektywie - ideologią. Rdzeniem tej ideologii, jak słusznie zauważył Robert Spaemann (ur. 1927), jest „dyktat nowoczesności”56. Rodzi się więc pytanie, co zrobić, aby filozofia, która stała się obecnie sferą przekonań, stała się na powrót sferą prawdy. Spaeman proponuje:

„Spod nowoczesnego światopoglądu można się wyzwolić nie przez «antymodernistyczną decyzję», nie przez rzucanie się w sieci, lecz jeśli w ogóle jest to możliwe, to przez oświecenie, tj. przez całkiem proste odkrycie, że sieć, w którą uwikłane jest myślenie, jest tylko siecią pomyślaną. Wówczas zaś natychmiastowe wyzwolenie jest kwestią chwili, gdyż już się dokonało. Nowoczesność jako «światopogląd naukowy», jako paradygmat bycia-w-świecie nie dysponuje żadnymi argumentami, opiera się na petitio principii. Jeśli ktoś zignoruje ten paradygmat i w kwestiach filozofii, religii i moralności nadal pyta o prawdę, a słów «dobry» $\mathrm{i}$ «zło» czy nawet słowa «Bóg» używa bez cudzysłowu, ten nie spotyka się z kontrargumentami, lecz z banalną formułą zastraszenia: tak dzisiaj nie można już mówić, myśleć ani pytać. Rzeczywiście nie? Dlaczego nie? Pewnego rodzaju niewrażliwość na tę formułę zawdzięczam temu (...), że nauczyłem się, że słowa «dobry» $\mathrm{i}$ «zły» nie są równoznaczne $z$ «nowy» i «stary” i że nowe czasy mogą mieć rację, ale mogą też jej nie mieć. Nie trzeba się zresztą tego uczyć. Wiedzą o tym dzieci. Nie wolno tylko pozwolić, aby ktoś wmówił nam, że jest inaczej"'57.

Andrzej Maryniarczyk ze swej strony przypomina, że właściwą „źródłową” nazwą metafizyki jest „,filozofia pierwsza”.

56 R. S p a e m a n n, Kroki poza siebie, (tłum.) J. Merecki, Warszawa 2012, s. 7.

57 Tamże, s. 8-9. 
„To pierwszeństwo - pisze - przysługiwało jej z dwóch powodów: po pierwsze dostarczała podstawowego i całościowego obrazu świata, na który składało się rozumienie bytów (rzeczy, roślin, zwierząt i ludzi). Po drugie dostarczała języka, którego główna funkcja wyrażała się w tym, że naprowadzał on na widzenie rzeczy. Terminy tego języka zostały wypracowane tak, by odsłaniały w rzeczach i w świecie to, czego język innych nauk nie może odsłonić" ${ }^{58}$.

W pierwszym aspekcie celem metafizyki jest poznanie dla samej tylko wiedzy (scire propter scire), spełniające naturalną potrzebę człowieka, jako bytu rozumnego. W aspekcie drugim metafizyka stanowi podstawę dla innych nauk i dyscyplin wiedzy, jest ancilla scientiae, dostarcza im adekwatnego obrazu przedmiotu, który badają we właściwym sobie aspekcie. Tymczasem dziś nauki same tworzą sobie „rozumienia bazowe” nie mając ku temu właściwych narzędzi. Rozumienia te bywają nie tylko ,kulawe”, ale po prostu błędne. Do tego dochodzi fałszująca rzeczywistość zmiana języka, np. słowo Bóg zastępuje się terminem sacrum, słowo byt - terminem ,przedmiot”. Nie trzeba przeprowadzać głębokich analiz, by zorientować się, ze Bóg to nie to samo, co sacrum, a byt nie to samo, co przedmiot.

Nie ma więc ucieczki od metafizyki, rozumianej jak wyjściowa problematyka filozoficzna, bo nie ma ucieczki od pytań metafizycznych, pytań o zasady i przyczyny, o to, co istnieje, co jest istotne, co stanowi cel tego, co istnieje. Staranna analiza metafizyczna wskazuje przede wszystkim, że jest nieprzekraczalna granica pomiędzy bytem, czyli tym, co ma w sobie powód tego że jest i czym jest, a wytworem, którego istotą jest zadana mu funkcja. I nie ma tu znaczenia, czy jest to jakieś proste narzędzie, czy komputer szybkością operacji prześcigający wielokrotnie ludzkie mózgi. Maszyna nie zastąpi więc człowieka, ani zresztą jakiegokolwiek innego bytu, z racji tego też,

58 A. M a ry n i r c z y k, Cóż po filozofii św. Tomasza z Akwinu w czasach postmetafizycznych? art. cyt., s. 13-14. 
że nie urealnia jej własne, stworzone istnienie, które zapoczątkowuje każdy byt naturalny. Realność naszych wytworów jest pochodną ich składników, z których je budujemy. Nie nadajemy im ich własnego, organizującego je aktu, bo nie mamy takiej mocy. Wytwarzamy, to znaczy łączymy zastane tworzywa w nowe kompozycje dla spełniania zadanych im funkcji. Nie stwarzamy, to znaczy nie powodujemy powstania pochodnego aktu istnienia, który zapoczątkowuje i urealnia każdy byt jednostkowy. Projekt transhumanistyczny nie może więc się nigdy ziścić, bo człowiek nie może zastąpić Boga. I nie chodzi tu o „stanowisko” lub pozycję, lecz strukturę bytową, która Bogu z racji jego samoistności umożliwia stwarzanie pochodnych aktów istnienia; struktura zaś człowieka takiej możliwości nie daje.

Podobnie staranna analiza metafizyczna bytu ludzkiego wskazuje, że nie stanowi go wyłącznie zespół cech, które można dowolnie przekształcać lub zmieniać. Żaden też komputer nie zastąpi ludzkiego intelektu. Człowiek jako osoba, stanowiąca duchowo-cielesną jedność jest jak każdy byt zdeterminowana w tym, czym jest, przez formę, która stanowi w nim akt jego istoty i która nie podlega formacji, deformacji, transformacji czy reformacji. Jest aktem istoty, czyli pewną faktycznością, czymś determinującym (kształtującym) możność, pewnym constans istoty. Ta forma wyznacza w bycie ludzkim zarówno jego duchowy jak i cielesny element i powoduje ich pewną jedność. Dzieje ludzkości dowodzą, że zbytnie przechylenie w którakolwiek stronę (wyłącznie ciała lub wyłącznie ducha) nie służą człowiekowi i powodują zazwyczaj opłakane skutki. Transhumanistyczna redukcja człowieka tylko do ciała eliminuje cały jego wymiar duchowy i podobnie jak zalecane w transhumanizmie „kolekcjonowanie” doświadczeń seksualnych nie zastąpi relacji osobowych z innymi ${ }^{59}$. Podobna redukcja człowieka wyłącznie do świadomości radykalnie ograniczy ludzkie poznanie i działanie, i w żadnym wypadku nie uczyni z człowieka anioła, czyli samodzielnego (substancjalnego) duchowego bytu osobowego, lecz raczej

59 Zob. A. A ndrzeju k, Tomistyczna «la révolution sexuelle» o. Adriano Olivy OP, „Studia Theologica Varsaviensia”, 54(2016) nr 1, s. 223-247. 
coś na kształt anima separata - duszę człowieka po śmierci ciała, pozbawioną możliwości naturalnego (zmysłowo-intelektualnego) poznania i działania, które dokonuje się przez organy cielesne.

Projekty więc modernizmu, postmodernizmu i transhumanizmu wymagają na nowo przemyślenia w perspektywie metafizycznego poznania prawdy o bycie, człowieku i Bogu.

\section{Streszczenie}

Artykuł podzielony jest na cztery części w których omawia się kolejno:

1) antropologię końca XIX i połowy XIX w., polegającą na ewolucyjnym pojmowaniu nie tylko genezy człowieka, lecz także jego osobowości, psychiki, kultury i moralności. Ujęciu temu przeciwstawiono tomistyczną teorię człowieka jako osoby, która także w tym czasie została opracowana. Człowieka rozumianego jako osoba charakteryzuje intelektualne poznawanie otaczającej go rzeczywistości, wolność w podejmowaniu działania oraz odnoszenie się miłością do innych osób, przekraczającą czysto fizyczne relacje. Tak pojęty byt ludzki stoi w opozycji wobec każdego redukcjonizmu: biologicznego, socjologicznego, kulturowego, ekonomicznego, prawniczego. Człowiek jako osoba wyrasta ponad to, co fizyczne, także ponad swoje ciało, które stanowiąc integralną część bytu ludzkiego nie wchodzi do definicji osoby. Takie ujęcie człowieka powoduje, że nie można go zredukować do jego ciała, co jest oczywiste, ale także, że cielesność człowieka nie stanowi centralnego tematu antropologii, gdyż jest nim osoba. Powoduje to w konsekwencji odsunięcie na dalszy plan problemu pochodzenia ciała i z tej perspektywy nawet przyjęcie ewolucyjnego genezy organów cielesnych nie stanowi podstawy do negowania stwórczej roli Boga w powstawaniu człowieka.

2) antropologię postmodernizmu charakteryzuje „płynność” określenia tego, kim jest człowiek. Powodowane jest to „przygodnością” człowieka, która wskazuje na indywidualność, różnorodność, brak możliwości jednej metafizyki, która mogłaby obejmować wszystkie przedmioty. Człowiek postmoderny wyznaje historycyzm (ujmowanie zjawisk z punktu widzenia ich historycznej ewolucji) i nominalizm (istnieją tylko jednostki i ich konwencjonalne nazwy), dzięki czemu może porzucić wszelkie metanarracyjne próby opisu istoty rzeczy. Tworzy za to własny język metafor, którego może używać w sposób całkowicie swobodny i dowolny. Z punktu widzenia teorii 
człowieka jako osoby postmodernizm jawi się jako reakcja na redukcjonizm biologiczno-społeczno-kulturowy jaki zafundowała człowiekowi nauka XIX i XX wieku z jej scjentyzmem i technokracją. Wydaje się, że w tym kontekście można zwrócić uwagę na klasyczne cechy osoby (constitutiva personae), takie jak jednostkowość, intelektualny charakter i wolność osoby ludzkiej, które w sumie powodują jej podmiotowość i daleko idącą autonomię.

3) antropologia transhumanizmu postuluje szerokie wykorzystanie nauk medycznych (łącznie z manipulacjami kodem DNA) i zaawansowanej technologii w rozwój człowieka, doprowadzający do jego gatunkowej przemiany w postczłowieka i rozpoczynając nową epokę dziejów, zwaną posthumanizmem. Postludzie będą istotami o znacznie większych możliwościach niż obecne istoty ludzkie. W dyskusji z transhumanizmem odwołano się w artykule do fundamentalnych paradygmatów myślenia filozoficznego - platonizmu i arystotelizmu. Uznano, że transhumanizm stanowi formę platonizmu z jego marzeniem angelizacji lub ubóstwienia człowieka. Wynika to z koncepcji człowieka jako wyłącznie zespołu cech i relacji „,mechanicznie” do siebie dodanych. Według arystotelizmu forma bytu ludzkiego jest w swej istocie niezmienna, a zmieniają się tylko własności i relacje, podmiotowane przez tę istotę. Tomistyczna teoria osoby należy do grupy filozofii pochodzących ze szkoły arystotelesowskiej i przy dopuszczeniu szerokiego wachlarza zmienności cech i relacji, nie uważa, aby były one w stanie zmienić swój podmiot - osobę ludzką - w coś innego.

4) filozofowie społeczni i filozofujący socjologowie rejestrują szereg negatywnych zjawisk antropologicznych, związanych $\mathrm{z}$ wprowadzanym już „projektem” postmodernistycznym i transhumanistycznym. Są nimi przede wszystkim nihilizm, scjentyzm, materializm, zagubienie tożsamości, co w dziedzinie ludzkiej kultury skutkuje jej infantylizacja (,zabawa na śmierć), w dziedzinie gospodarczej - ekonomią nadmiaru i braku, czyli ciągłego pogłębiania się różnić majątkowych (,twierdze bogatych i getta biednych”), w dziedzinie zdrowia - pogorszeniem się kondycji psychicznej człowieka. Proponuje się, aby podmiotowe i osobowe ujęcie człowieka przeciwstawić skrajnemu scjentyzmowi, nihilizmowi oraz przedmiotowemu i utylitarnemu wykorzystaniu człowieka dla korzyści i przyjemności. Odkrycie siebie jako osoby może być dla człowieka drogą do poznania siebie i przezwyciężenia pogłębiającego się kryzysu tożsamości. Podkreślanie godności osoby ludzkiej i troska o wspólne dobro może być próbą wyjścia z cywilizacji nadmiaru i braku. Nawiązanie relacji osobowych i troska o drugiego może zahamować zjawisko rozpadu więzi międzyludzkich, samotności i utraty poczucia 
bezpieczeństwa oraz może wpłynąć na poprawienie się pogarszającej się kondycji duchowej ponowoczesnego człowieka.

\section{Thomistic personalism against modern and postmodern anthropology Summary}

The article is divided into four parts which discuss the following subjects:

1) Anthropology of the late 19th and mid-19th century - consisting in the evolutionary understanding of not only the genesis of man but also his personality, psyche, culture and morality. This approach contrasted with the Thomistic theory of man as a person, which was developed also at this time. Man understood as a person can be characterized by the intellectual perception of the surrounding reality, the freedom to act, and the love for others which goes beyond purely physical relations. A human being understood in such a way stands in opposition to every form of reductionism: biological, sociological, cultural, economic, and legal. Man as a person grows above the physical, also above his body which - despite being an integral part of human existence does not fall within the definition of a person. According to this view, man cannot be reduced to his body, which is obvious, but also carnality does not constitute a central theme of anthropology, that being a person. As a consequence, the problem of the origin of the body becomes secondary and from this perspective, even the acceptance of the evolutionary origin of the bodily organs does not constitute a ground for negating the creative role of God in the formation of man.

2) Anthropology of postmodernism is characterized by the "fluidity" of the definition of man. This is caused by the "contingency" of man, which points to individuality, diversity and lack of one metaphysics that could cover all objects. A postmodern man believes in historicism (looking at phenomena from the point of view of their historical evolution) and nominalism (there are only individuals and their conventional names), so he can abandon any metanarrative attempts to describe the essence of things. He creates his own language of metaphors which he can use absolutely freely. According to the theory of man as a person, postmodernism appears as a reaction to the biological and socio-cultural reductionism that the science of the 19th and 20th century - with its scientism and technocracy - offered to man. It seems that in this context one can pay attention to the typical characteristics of 
a person (constitutiva personae), such as individuality, intellectual character and freedom of the human being, which all give rise to its subjectivity and far-reaching autonomy.

3) Anthropology of transhumanism advocates the widespread use of medical science (including manipulation of the DNA code) and advanced technology in human development, leading to the transformation of man into the posthuman and beginning a new epoch of history called posthumanism. Posthumans will be beings with far greater capabilities than human beings today. In a discussion with transhumanism, the article referred to the fundamental paradigms of philosophical thinking - Platonism and Aristotelianism. It was considered that transhumanism is a form of Platonism with its dream of making man angelic or divine. It results from the concept of man as only the set of attributes and relations "mechanically" added to each other. According to Aristotelianism, the form of human being is immutable in its essence, and it is only the properties and relationships of a human being that change. The Thomistic theory of a person belongs to a group of philosophies originating from the Aristotelian school and - allowing for a great variability of features and relationships - it does not consider them to be able to change their subject - a human being into something else.

4) Social philosophers and philosophical sociologists record a number of negative anthropological phenomena related to the already existing postmodern and transhumanist "project". These include primarily nihilism, scientism, materialism, and identity loss, all of which results in the infantilization of the human culture, and - in the economic field - in the economy of excess and lack, i.e. the continuous deepening of financial differences (fortifications of the rich and ghettos of the poor), while in the area of health it leads to the deterioration of the mental condition of man. It is suggested that the subjective and personal approach to man be opposed to extreme scientism, nihilism and the objective and utilitarian use of man for the benefit and pleasure. Finding oneself as a person can be a way for people to get to know themselves and overcome a deepening identity crisis. Emphasizing the dignity of the person and concern for the common good may be an attempt to leave the civilization of excess and lack. Establishing personal relationships and caring for others can inhibit the breakdown of interpersonal relationships, loneliness and the loss of a sense of security, and it may help improve the deteriorating spiritual condition of the postmodern human. 
Słowa kluczowe: ewolucjonizm, personalizm, postmodernizm, tomizm, transhumanizm

Keywords: Evolutionism, Personalism, Postmodernism, Thomism, Transhumanism

Nota o autorze: Artur Andrzejuk - prof. dr hab. - kierownik Katedry Historii Filozofii Starożytnej i Średniowiecznej UKSW. Specjalizuje się w dziejach filozofii średniowiecznej, szczególnie nurtu arystotelesowskiego, w tym filozofią i teologią Tomasza z Akwinu.

\section{Bibliografia:}

Andrzejuk A., Etyka chronienia osób. Zarys problematyki, „Rocznik Tomistyczny” 3 (2014), s. 23-41.

Andrzejuk A., Jaki personalizm? Szerokie i wąskie rozumienie personalizmu, w: Personalizmus a súčasnost'. Zborník príspevkov z medzinárodnej vedeckiej konferencie, red. P. Dancák, Prešov 2010, s. 19 - 25.

Andrzejuk A., Tomistyczna «la révolution sexuelle» o. Adriano Olivy OP, „Studia Theologica Varsaviensia", 54(2016)1, s. 223-247.

Bauman Z., Dwa szkice o moralności ponowoczesnej, Warszawa 1994.

Bauman Z., 44 listy ze świata plynnej nowoczesności, (tłum.) T. Kunz, Kraków 2011. Bauman Z., Płynna nowoczesność, (tłum.) T. Kunz, Kraków 2007.

Bauman Z., Plynne życie, Kraków 2007.

Bauman Z., Wspólnota, (tłum.) J. Margański, Kraków 2008.

Bauman Z., Życie na przemiał, Kraków 2006.

Bostrom N., The Transhumanist FAQ, version 2.1, Oxford 2003.

Bostrom N., Transhumanist Values, w: Ethical Issues for the 21st Century, red. F. Adams, Philosophical Documentation Center Press, Charlottesville 2003.

Chenu M.-D., Wstęp do filozofii św. Tomasza z Akwinu, (tłum.) H. Rosnerowa, Warszawa 1974.

Dancák P., Personalizmus a paideia, spoločné wýchodiská a ciele, w: Presonalizmus v procese humanizácie l’udskej spoločnosti, red. P. Dancák, Prešov 2014, s. 46-59.

FM-2030 (Fereidoun M. Esfandiary), Are You a Transhuman?: Monitoring and Stimulating Your Personal Rate of Growth in a Rapidly Changing World, New York 1989.

Fukuyama F., Koniec człowiek. Konsekwencje rewolucji biotechnologicznej, (tłum.) B. Pietrzyk, Kraków 2004. 
Gogacz M., Elementarz metafizyki, Warszawa 2008.

Gogacz M., Platonizm i arystotelizm (dwie drogi do metafizyki), Warszawa 1996.

Gontarczyk P., Nowe klopoty z historiq. Publicystyka z lat 2005-2008, Warszawa 2008.

Grabowska T., Zagrożenia bezpieczeństwa społecznego w ideologii transhumani$z m u$, „Kultura Bezpieczeństwa. Nauka - Praktyka - Refleksje”, 18(2015), s. 53.

Huxley A., Nowy wspaniały świat, (tłum.) B. Baran, Warszawa 2011.

Huxley J., In New Bottles for New Wine, London 1957.

Jan Paweł II, Encyklika Fides et Ratio, 64, w: Encykliki Ojca Świętego Jana Pawła II, Kraków 2007.

Kiereś B., Personalizacja człowieka - od osoby do osobowości, w: Presonalizmus v procese humanizácie l’udskej spoločnosti, red. P. Dancák, Prešov 2014, s. 210.

Krąpiec M., Osoba, w: Powszechna Encyklopedia Filozofii, t. 7, red. A. Maryniarczyk, Lublin 2006, s. 881.

Lyotard J.-F., Kondycja ponowoczesna. Raport o stanie wiedzy, (tłum.) M. Kowalska, J. Migasiński, Warszawa 1997.

Maryniarczyk A., Cóż po filozofii św. Tomasza z Akwinu w czasach postmetafizycznych? „Rocznik Tomistyczny”, 3(2014), s. 11.

More M., Transhumanism: Towards a Futurist Philosophy, „Extropy \#6”, 1990.

Musil R., Człowiek bez właściwości, (tłum.) K. Radziwiłł, K. Truchanowski, J. Zeltzer, wyd. 1, Warszawa 1971 (wyd. 2, Warszawa 2000 - 2002).

Orwell G., Rok 1984, (tłum.) T. Mirkowicz, Warszawa 2013.

Reale G., Zło nękające wspótczesnego człowieka i lekarstwo, które można na nie znaleźć w myśli antycznej, (tłum.) E. I. Zieliński, „Ethos”, 14(2001) nr 56, s. 15-39.

Rorty R., Przygodność, ironia i solidarność, (tłum.) J. W. Popowski, Warszawa 2008.

Spaemann R., Kroki poza siebie, (tłum.) J. Merecki, Warszawa 2012.

Surma-Gawłowska M., Zawadzki A., (wybór, przekład i opracowanie), Myśl mocna, myśl słaba. Hermeneutyka włoska od połowy XX wieku. Antologia tekstów, Kraków 2015.

Szymański K., Transhumanizm, „Kultura i Wartości”, 13(2015), s. 133-152.

Szymański K., Transhumanizm: utopia czy ekstropia? „Idea. Studia nad strukturą i rozwojem pojęć filozoficznych", 27(2015), s. 159-175.

Tichy R., Gwiazdy naszym przeznaczeniem. Chrześcijańskie korzenie transhumanizmu, „Czterdzieści i cztery. Magazyn Apokaliptyczny”, 8(2016), s. 4-43.

Tichy R., Mesjańskie oblicze transhumanizmu, „Czterdzieści i cztery. Magazyn Apokaliptyczny", 8(2016), s. 164-183.

Wolska U., Wizja czlowieka ponowoczesnego a tomistyczna teoria osoby, „, Rocznik Tomistyczny" 4(2015) s. 191-214. 